\title{
De-Universalising Male Normativity: Feminist Methodologies for Studying Masculinity in Premodern Islamic Ethics Texts
}

\author{
Zahra Ayubi \\ Department of Religion, Dartmouth College, Hanover, NH, USA \\ zahra.ayubi@dartmouth.edu
}

\begin{abstract}
Historically, texts of the Islamic intellectual tradition characterised the ideal Muslim by exclusively referring to men and their concerns. Only recently have scholars of Islam begun to engage in critical study of the category of masculinity. This essay focuses on theories and methodologies of studying masculinity and manhood in premodern Islamic ethics. I demonstrate the gains to be made from gender-critical study of masculinity by way of consolidating approaches scholars have taken and arguing for feminist reasons and methodologies for unpacking male normativity. Because premodern Islamic ethics texts across multiple genres of the scriptural and intellectual tradition presume male readers and subjects, we must take male normativity, the assumption that Muslim ethics is for men, male bodies and practiced by persons marked by maleness, as our critical starting point.
\end{abstract}

\section{Keywords}

Islamic ethics - masculinity - manhood - muruwwa - non-binary gender - gender ethics - feminism - theory and method

* I wrote this article in conversation with the scholarship presented at a symposium on manliness in Islamic ethics, which with the exception of Sa'diyya Shaikh's paper, did not employ a gender critical lens. My sincere thanks go to Cyrus Zargar for finding my critical lens on masculinity important to include in the symposium and this special issue. Thanks also to the anonymous peer-reviewers of this article, whose comments helped me refine my contribution in relation to existing scholarship. I hope this article and this special issue will push the critical study of masculinity in Islamic ethics forward. 


\section{الخلاصة}

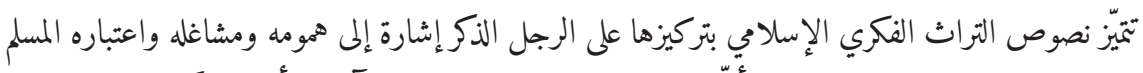

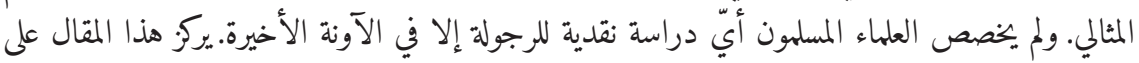

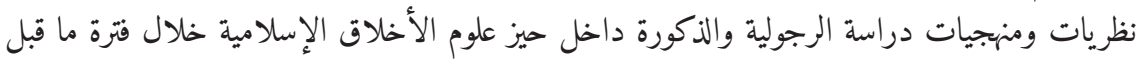

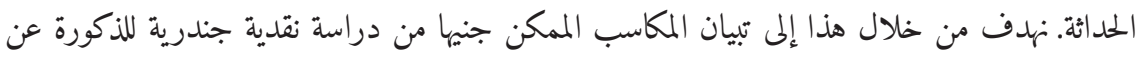

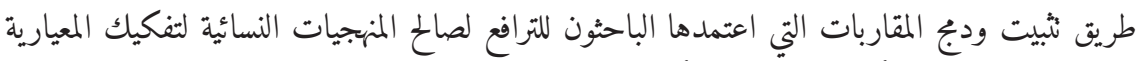

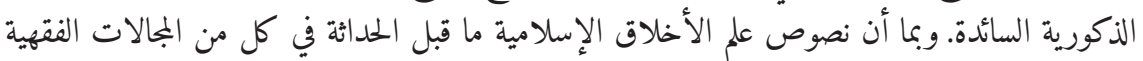

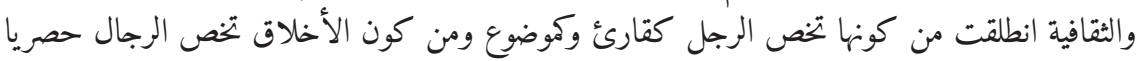

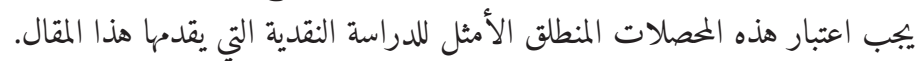

\section{الكلمات المفتاحية}

النمل الأخلاق الإسلامية - الأخلاق - الرجولة والرجولية ثنائية النوع - المروءة - أخلاق النوع (الجندر) -

Historically, texts of the Islamic ethical tradition have characterised the ideal Muslim in ways that exclusively refer to men and their concerns. Although scholars of Islam have spent comparatively longer thinking about women and femininity, they have only recently begun to engage in critical study of the category of masculinity. In this essay, I argue for feminist methods for studying masculinity that centres around critical examination of gender, particularly constructions of masculine traits and manhood for the purpose of deconstructing the historical, philosophical, and ethical substrates of patriarchy in Islamic thought. To do this, I first make the feminist case for studying masculinity in Islamic ethics. I then demonstrate the gains to be made from gendercritical study of masculinity by way of consolidating approaches scholars have taken and arguing for feminist reasons and methodologies for unpacking male normativity. It is important to study masculinity in premodern Islamic ethics texts because it is in these works that we can deconstruct the particularly male-centred aspects of prescriptive voices which comprise multiple genres of the Islamic scriptural and intellectual tradition. Because Islamic ethics texts presume male readers and male subjects, we must take male normativity, the assumption that Muslim ethics is for men, male bodies, and practiced by persons marked by maleness, as our critical starting point. 
From a feminist perspective, shifting to a study of gender that includes masculinity allows us to understand more fully how masculinity is shaped over and against femininity. It allows us to ask questions such as: how has Muslim manhood been constructed such that it relies on the instrumentalisation and subjugation of women? How does Muslim manhood require and contribute to patriarchal gender relations? How do prescriptions of gender segregation create masculine norms? What does male normativity entail? Although I discuss strategies for textual analysis below, there are many sociological or social history questions that the study of masculinity opens up such as: how does the patriarchal order of society affect boys' and men's sense of what is expected of them? How do men suffer from idealised forms of masculinity? And in what ways do class, race, sexuality, or ability contribute to or shape Muslim masculinity?

Here in this essay, I define premodern Islamic ethics as a prescriptive religious discourse that defines the moral ethos of Islamic behaviour. In recent work, I define Islamic ethics as an academic construct "which scholars have used to describe the values imparted in various genres of the Islamic tradition, including Qur'ān and Hadìth, which I treat together as the scriptural ethics tradition; the intellectual ethics tradition including fiqh (jurisprudence), Sufism, kaläm (theology), akhlāq (philosophical ethics); and adab (literature)" (Ayubi 2020). Additionally, Muslim praxis (that is, life lived according to an Islamic ethos) is often described as Islamic ethics, but the question of whether or not practices adhere to textual ethics requires social history work with archival material or ethnographic work. I cast this wide cross-genre net because no one genre can complete an Islamic picture of what defines the good Muslim subject and moral life, and scholars who have studied Muslim masculinity in prescriptive discourses specialise in a wide variety of texts and contexts.

Currently, scholars have produced a fairly significant amount of scholarship on masculinity and manhood in Islam and Muslim societies, and it is only just starting to coalesce as its own subfield within the study of gender in Islam. However, there are many for whom it is unclear why there must be a study of masculinity in Islam or what we get out of it. To be clear, the study of masculinity in the Islamic ethics tradition is not an attempt to overthrow it, but rather to clarify its gendered nature in order to get at a deeper philosophical understanding of being, selfhood, and moral impetus in Islam.

As Omaima Abou-Bakr, Marion Katz, and Kecia Ali have all pointed out, the current state of critical study of masculinity in Islamic ethics and Muslim praxis shows serious room for growth. Nevertheless, over the past two decades, scholars have sporadically published important examinations of masculinity, much of which is focused on contemporary concerns, especially from sociological 
perspectives such as political participation, sexuality, fertility, marriage practices, or radicalisation (Inhorn 2012; Gerami 2005). Within those discourses, faithful modernist discourses on masculinity emphasise gender differences based on biological essentialism (Abou-Bakr 2013, 99). Closer to our interests, some notable scholarship focuses on premodern concepts of normative masculinity in a variety of textual ethics sources, particularly those that have examined the Qur'ānic prophets (De Sondy 2015), tafsir (Abou-Bakr 2013), the Prophet Muhammad's manhood (Ali 2014; Tanner Rhodes 2018), that of the twelve Shīīi imams (Pierce 2016), futuwwa (Sufi chivalry) (Ridgeon 2011; Kugle 2010), and ethics (Ayubi 2019; Katz 2019), law (Ali 2010; Katz 2014). ${ }^{1}$ Scholars have also studied topics such as ghayra (Katz 2019; Myrne 2019), elite male normativity of ethics and homosocial relations (Ayubi 2019a), and ideas about masculinity in gender diversity and non-binary gender orientations in premodern sources (Geissinger 2020; Gesink 2018; Rowson 1991; Marmon 1995).

These studies are foundational in a nascent field of works on premodern Islamic ethics texts and, together, demonstrate that a single definition of Islamic masculinity does not exist in the premodern spiritual and intellectual tradition, and highlight the need for critical gender scholarship on masculinity and manhood in premodern Islamic ethics. For the most part, studies of masculinity in Islamic ethics has proceeded without a gender critical lens, despite their interest in discussions of muruwwa (ethical manhood) in futuwwa and javānmardī (Sufi chivalry and young manliness) literature. Such work makes assumptions about the universality of the male ethical subject, which is precisely what a feminist approach to studying masculinity in Islamic ethics deconstructs, and what I will elaborate on below with respect to the theoretical and methodological approaches they utilise.

\section{The Case for Studying Masculinity in Premodern Islamic Ethics}

Although scholars have made the case for studying Muslim masculinity in various contexts before, the staggered nature of research on the subject prompts me to make another appeal, this time specifically to scholars of Islamic ethics, as the study of masculinity in this area is especially fragmented. Historically, Islamic ethics texts have been presumed to be universally applicable to everyone, at least to every Muslim, but the tradition is normatively

1 It is worth noting here that scholars have written social histories of Muslim masculinity and gender diversity in various premodern Muslim contexts. See works by Shaun Marmon, Afsaneh Najmabadi, Khaled El-Rouayheb, Ahmed Ragab, and most recently Shireen Hamza. 
male. I have argued in my study of the akhlāq tradition that Islamic ethics itself requires that the central person in question, a man who is reading for his own refinement, relies on the service of others such as wives, children, servants, and enslaved persons to achieve that refinement (Ayubi 2019a, 115). Indeed, scholars have shown that other genres about how to be a good Muslim also presume that the primary subject is male, and necessitate similar service to him by subordinates, or at least that the primary male subject controls others (Shaikh 2012; Ali 2010; Geissinger 2020). If there is ever hope of a future Islamic ethics (or any ethics) that is ever inclusive and non-exploitative, we have to unpack this universalised male subject of Islamic ethics, and systematically study how masculinity is constructed.

There are two groups of scholars I wish to engage here: first, those who study premodern Islamic ethics texts who do not employ gender critical frameworks, and second, those who do. In the first group, there is no shortage of scholars who have employed interesting critical frameworks to study Islamic ethics, but have ignored gender as a category of investigation. While not all work on Islamic ethics needs to be specifically about gender, ignoring gender dimensions reifies the universalisation of the male subject, often in addition to other normative claims such as elitism or Arab-centrism to the exclusion of other cultures and races in the enterprise of ethics. Realising that ethics texts are by and for men is critical because it clarifies the selective nature of the texts that historically kept them - and by extension, their messages of how to live as a Muslim, the good life, ethical behaviour, and human existential purposefrom being universal, despite their potentially widespread applicability or contemporary scholars' desires to assume a universal audience. Although some scholars may recognise and view ethics texts' male normativity as an historical artifact, it is precisely through reflecting on concepts of gender that we get a sense of the exclusionary character of both the texts' audiences as well as the ethical precepts found in them.

If we are to take at their word scholars in our first group who wish to make connections between premodern and modern constructive Islamic ethics, the study of masculinity creates the foundation for a more inclusive Islamic ethics. Typically, having conceded that premodern texts are male-exclusive, these scholars question why it is not possible for us - in contemporary timesto simply include women or extend premodern Islamic ethics precepts to women-arguing that doing so would be a sufficient method for being inclusive now. This approach, whether stated explicitly or not, is evident in constructive works by contemporary religious leaders and sheikhs that draw on al-Ghazālī's (d. 505/1111) Kìmìyā-yi Sa'ādat and Ihyā' 'Ulüm al-Dìn, for example, as guides for ideal Muslim marriages, applicable to both husbands and wives, 
by emphasising al-Ghazālì's approach towards marriage as a means of "obtaining greater taqwa" (consciousness of God) and a "field of purifications and training" of one's own virtues (Saloojee 2017). However, as Kecia Ali has argued with respect to women taking advantage of the right to add stipulations in nikah contracts as "missing the forest for the trees," the arrangement is fundamentally unequal (Ali 2003, 164). Just adding women into a system of thought that is normatively male does not work because Islamic ethics is structurally male-centred. For example, we cannot just change al-Ghazālì's guidelines in the Kimmiyā-yi Sa'ädat or Ihy à 'Ulüm al-Dìn on how to be an ethical husband into how to be an ethical spouse, a seemingly gender-neutral shift, because the guidelines for a husband necessarily entail instrumentalising the wife for the husband's gains. It is not possible to just add women, or pretend that pronouns in the original texts in Arabic, Persian, Turkish, or Urdu etc. were gender neutral (Ayubi 2019a, 72). Rather, it is necessary for us to unpack how men and masculinity have been constructed in order to get at the root principles at play in the ethical tradition that lead to inequality and exclusivity such as exploitation of women, non-binary persons, and non-elites for the benefit of men. Only then can we begin to ask how ethical discourses can be more inclusive now.

More egregiously than simply failing to account for "invisible" women's supportive labour in ethics codes designed for men, some of the scholars who do not use gender as a lens for their work, have questioned the purpose of exposing androcentrism of Islamic ethics, stating that such an exercise only serves to create non-pre-existing gender rifts. Many of these scholars hold that Islam liberated women 1400 years ago and so the Qurānn, Sunna, and the Islamic intellectual tradition do not require feminist re-readings or interpretations. For them, Muslim culture might be the culprit. Scholars in this camp argue that feminist critiques of the Islamic tradition flouts unity of the Muslim community. They claim that feminist work acts "chauvinistically for women's interest alone" and propose that "Islamic traditions would dictate that women's progress be achieved in tandem with the wider struggle to benefit all members of the society" and "disadvantageous circumstances of women therefore should always be countered in conjunction with attempt to alleviate those factors which adversely affect men" (Ahmed 2009, 70). However, in this line of argumentation, scholars only value an equitable understanding of the tradition because they wish it to be true, while deeply disagreeing with the feminist deconstruction of male-centeredness and painting feminist scholars as "troublemakers." This resembles the "all lives matter" response, to the Black Lives Matter movement, which seeks to undermine anti-racist efforts under the pretence of demanding equality for all. 
Relatedly, Ziba Mir-Hosseini calls such a position neo-traditionalist because the sentiment that feminist scholars are causing ruptures to a perfect system, is in itself a defensive response to Western allegations that Islam is uniquely sexist while ignoring problematic fundamental gender asymmetries in the tradition (Mir-Hosseini 2003, 15-16). My argument here is that reflecting on the male normativity of premodern texts is precisely the way we can unpack why women have been left out of the ethics tradition. It also addresses anti-Muslim stereotypes about women's oppression in Islam because it shows richer engagement with gender discourses than simplistic stereotypes about the tradition convey. Charging scholars who are concerned with gender with creating rifts is tantamount to perpetuating the male normativity of sources, the harm of women's exclusion from them, and its effects on Muslim practices.

Addressing the second audience of scholars, those who do employ gendercritical frameworks in the study of Islamic ethics texts, I would like to discuss how feminist scholarly goals are served in studying masculinity. So far, feminist scholarship has focused on women, girls, and femininity in order to reflect on concepts of gender in the study of Islam and Muslim experience; taking a truly feminist stance in our scholarship, or at least deploying feminist theories and methods of feminist scholarship to a serious extent, necessitates studying masculinity also. The feminist study of patriarchy is incomplete without the study of masculinity.

One argument that feminist scholars of Islam may articulate against studying masculinity in Islamic ethics texts is that they are already by and for men so foregrounding masculinity would only serve to reify their androcentrism. However, the goals of feminist scholarship are not fully realised by just studying women or femininity. The study of masculinity strengthens feminist work because it questions male normativity and shows how "gender is relational" and that by studying the "social construction of masculinity" we can "call men's subordinate status into question" and "demonstrate that masculinity is one of the primary social forces currently stalling egalitarian social change" thus "[highlighting] contradictions and cleavages where [superordinate] masculinity can be most effectively attacked" (Peretz 2016, 30-32). The study of men and masculinity is, therefore, necessary for the feminist scholarly project of deconstructing Islamic ethics.

Yet, some theoretical discussion is required to make the scholarly commitment to move away from just studying women in the Islamic tradition to studying gender in the Islamic tradition, especially premodern ethics discourses. The study of women-only stems from a long-standing desire to understand women's "true status" in Islam, among Muslims, in texts, or history. Often, the 
framing of studying women as a category or women's "status" implies that there can be a singular understanding of who women are, of women's ontology, and women's roles as though they are static and unchanging over time. As Kecia Ali notes, the question of women's status is often about an idealised Islam, mostly referring to isolated passages from the Islamic scriptural traditions and sometimes including jurisprudence; however "analyzing isolated passages from these sources is not likely to give an accurate portrayal of women's rights, nor do these sources necessarily reflect actual practice" (Ali 2002, 91). More pressingly for our purposes, the framing of "women's status" has forced scholars to unyieldingly study women and femininity as subjects, instead of fully engaging gender as a category of investigation.

This fixation on women's status is itself an enduring response to the enduring orientalist presentations of Muslim women as oppressed by their men and their tradition. The continuous responses to that presentation-either from within or outside the tradition - range from defensive of women's status (similar to arguments I discussed above), apologetic for women's status, or critical of women's status. As Shabana Mir has pointed out, in many ways the study of Muslim women and gender in Islam will always be post-orientalist in the sense that scholars will always have to engage with the orientalist and neoorientalist critiques about these topics in some way (Mir 2014, 182). But as Carl Ernst and Richard Martin suggest, scholars in Islamic studies need to create new knowledge within Islamic studies and carry on with interesting scholarship by sidestepping the orientalist call-and-response demanded of them to ensure that the study of Islam moves beyond the "intellectual ghetto of philological specialization that remains impenetrable to outsiders" and confines the study of Islam (Ernst and Martin 2010, 14). For the study of gender in Islam, that would mean moving beyond just studying women in the Qur'ān and Islamic law.

I want to be clear that even though I argue that studying men and masculinity is important, there is still great value in studying women in texts, social history, and real life, because of the systematic, historical erasure of women in the study of Islam; because studies that involve real Muslim women force us to confront women's experiences of how Muslim traditions, communities, or families support or fail them; and because women's experiences teach us about alternative visions of Islamic praxis. However, a better understanding of the building blocks of Muslim masculinity and Islamic and ethical manhood, leads us to its deconstruction and back to the feminist scholarly purpose, which is to advocate for gender justice and egalitarian visions of Islam or the study of Islam. In other words, advocacy for women and gender justice is incomplete without analysing, and problematising, Muslim masculinity and manhood. 
Masculinity is a construct that describes various qualities of a person that are associated with maleness, manhood, or the qualities of being a man. Women, and non-binary persons may indeed possess some masculine qualities as well, just as they may possess, and men may possess, feminine qualities also. For example, I have shown that in philosophical ethics texts of al-Ghazālì (d. 505/1111), Nașīr al-Dīn Ṭūsī (d. 672/1274), and Jalāl al-Dīn Davānī (d. 908/15o2) women too were thought to possess 'iffa (self-restraint), but the trait's perfect embodiment could only be found in men (Ayubi 2019, 82-83). In another example, Marion Katz has shown that ghayra, can refer to a form of mere jealousy possessed by anyone, but if it refers to religious zeal, then, in the rendering of Ibn Qayyim alJawziyya (d. $75^{1 / 1350}$ ), it is a gendered male trait that women have no access to because it is considered a male virtue (Katz 2019, 203). While personal qualities are specific to individuals, the forces that shape them are cultural, familial, and institutional. Lahoucine Ouzgane has theorised that men from "a social constructionist perspective, [...] are not born; they are made; they construct their masculinities within particular social and historical contexts. Masculinities in Muslim contexts emerge as a set of distinctive practices defined by men's positioning within a variety of religious and social structures" (Ouzgane 2006, 46). Along with economic, relational, sexual, and other forces, religious institutions (Connell 2001, 29), or for our interests, the premodern prescriptive Islamic ethics texts that emerged from them, create concepts of idealised Muslim male behaviour and existential purpose. So in this sense, while anyone may possess the specific masculine traits, my focus is on the ethical valance of masculinity as it is "rightly" embodied by "good" or "bad" men. As I show below, the richness of discourses about what normatively defines ethical Muslimhood and the good life also serves as a gender debate over what defines manhood.

In this section, I will discuss the theoretical shift we must make in order to study masculinity despite the fact that in scholarship, gender has become synonymous with women and male has been synonymous with the universal. Then, in the remainder of this essay, I will demonstrate some feminist dividends of studying masculinity by way of non-exhaustively reviewing methodologies scholars have taken to study masculinity in premodern Islamic ethics texts. Although the works vary in their intensity of critical engagement with concepts of gender, I review them to distil or categorise methodological approaches into the following non-exhaustive five groups: 1) ideal men in ethics discourses; 2) correctives of hegemonic masculinity; 3) non-binary gender references; 4) homosociality, the building blocks of patriarchy; and 5) contrast with femininity. 


\subsection{Shifting Perspectives to De-Universalise Male Normativity}

Understanding constructions of masculinity in Islamic ethics texts requires us to critically note male normativity and the assumed male universality of the ethical subject. Studying masculinity is a subtle but important shift away from how we are accustomed to studying gender in texts - which is often to search for mentions of women or interactions with women. To begin with, it is important to recognise that scholars, including conventionally trained women, have been studying only men and masculinity without saying so because they may not have contemplated the category of gender at play in the normative male gaze upon Muslim texts. In other words, they have not recognised that "men have gender too" (Ali 2012). Moving forward, we must make a conscientious effort to recognise that the normative human being is male in almost all premodern and many modern Muslim ethics texts; only with that consciousness can we intervene in how that maleness or masculinity is constructed.

De-universalising male normativity involves deliberately analysing moral/ ethical guidelines as explanations of who idealised men are; that is, to read how the texts substantively define ethical subjects considering their original normative male intent. Scholars who are used to associating only women with gender may start by asking the question of who is the intended reader of a given text in question, and how is the reader supposed to act towards people who are not part of the intended audience. We find that texts of the Islamic intellectual tradition are not only by men, which obviously invests male bias in them, as Leila Ahmed famously argued when she first called our attention to the male centred nature of Islamic texts (Ahmed 1992), but they are also for men to read and implement in their lives. The texts, exegetical, legal, mystical, philosophical, and otherwise, obviously still have everything to do with women and there are many close readings of women's status in the classical prescriptive texts of Muslims, but because they were written by and for men, we can read them to understand what kind of manhood the texts are constructing and bolstering, at what costs, and in relation to whom. Omaima Abou-Bakr has called this shift in perspective in gender studies "turning the tables" from the study of women to the study of men (Abou-Bakr 2013, 90). Questioning the audience in the context of probing the history of texts is key to understanding the gender dynamics in play at the time, even when women seem to be absent.

In addition to the audience, authorship is also important to historically accounting for the male normativity of Islamic ethics texts. In his study of biographies of the twelve Shīi imams, Matthew Pierce notes that "the depictions of the imams reflect the circumstances and identities of the men who wrote about them: they are portrayed as capable, urban men of letters who know 
lifegiving secrets but were prevented from taking full leadership by their adversaries" (Pierce 2016, 105). Likewise, I note that ethicists reflexively ordered the ethical cosmos according to what benefitted them, and their male centred metaphysics and belief of men's superior ability to reason reflected their own, perhaps wishful, view of themselves (Ayubi 2019, 251). The male normativity in premodern Islamic ethics texts then comes from the fact that male ethicists were reflexively writing themselves into ethics. Put another way, because certain men wrote the Islamic ethics tradition, it is an exclusionary and male normative tradition in which the universal ethical subject, or the fully Muslim person, is a man.

After taking critical stock of a text's audience and authorship, the next steps to de-universalising male normativity would be to ask questions about the actions, status, role, and relationships of the primary ethical subject of the text, to whom the text speaks. How idealised men are defined requires scholars to look at textual examples involving specific or imagined men, and to ask what these male figures are doing, how are they meant to live their lives, how they are supposed to treat others, and what personality traits or physical characteristics are associated with them. How is idealised masculinity achieved? In particular, their imagined relationships with others, and ideal conduct in relation to others, are most telling of the central ethical subject himself. What kind of a husband, father, boss, slave owner, or friend, is he positioned to be? Is he imagined to have great wealth, assumed to be Arab, own slaves, be a member of the 'ulama' (body of Muslim scholars) or court, visit the public bath, make a public show of his piety, and so on? What indicators do we have that the primary ethical subject is a man and what kind of man is he? Asking whether someone other than a man could possess the characteristics and perform the behaviours that the central ethical subject is expected to do, such as women, enslaved or non-binary individuals, clarifies the male normativity and paints a picture of idealised masculinity.

Because so much of existing scholarship on Islamic ethics is normatively male, much of it can be revisited from the critical standpoint that universals in both scholarly works and their primary source material have been exclusionary and really about men or masculinity. For example, Cyrus Zargar's The Polished Mirror (2017) is not specifically asking gender critical questions, but his analysis of narrative and storytelling demonstrates a premodern ethical means of constructing and communicating idealised moral qualities of premodern Muslim men. He focuses on how philosophical and Sufi narratives by Rūmī (d. 672/1273), al-Ghazālī, Ibn Sīnā (Avicenna, d. 428/1037) and others utilised narratives and storytelling to produce ethical knowledge. In one instance, Zargar shows how Rumi uses the characters of the Judge and Sufi 
in his Mathnawi to examine the complexity of human justice, communicating to male readers that enacting human justice requires one "to overcome the tugs of one's nature," "[gather] in oneself all virtuous qualities," and to weight the consequences of one's decisions and actions on all parties involved (Zargar 2017, 286). The story tells us how Rumi imagined authoritative men could enact justice through their own self-discipline and self-reflection on the weight of moral responsibility towards others. If we de-universalise male normativity from his work, we can be deliberate about how the ethical male character emerges in relation to those over whom he has authority, just as he has authority over his own nature. We can also learn about men's use of storytelling, male forms of spiritual knowledge transmission, and we can contrast it with that of women too. ${ }^{2}$ Recasting Zargar's analysis as a study of how manhoods are constructed in primary sources medieval ethics poetry provides us with a view of how masculinity is not static. By paying this kind of attention to ethics source texts like his, we can reveal new, and at times competing, constructions of idealised Muslim masculinities.

\subsection{The Manhood of Prophets and Saints in Premodern Islamic Ethics}

It is a common rhetorical move in religious discourses and khutbas (sermons) that speak to women to prescribe the roles and behaviours of the Mothers of the Believers, the wives, daughters, and sometimes the female companions of the Prophet. Accordingly, scholars have analysed the figures of 'A'isha (d. 58/678), Khadīja (d. 619), Fāțima (d. 11/632) and others (Ali 2014; Gabbay 2020; Spellberg 1994; Stowasser 1994) to understand how stories about these exemplary women contribute to gender roles in Islam. Analogously, scholars who have taken critical gender lenses to analyse masculinity in male exemplars, not only tell us how those masculinity of those figures create morality, but specifically how they create an Islamic ethics of patriarchy.

Scholars who have studied ideal men focus in the Islamic scriptural and biographical traditions have shown that their gender and masculinity is integral to understanding them as exemplars of Islamic morality. Works by Amanullah De Sondy, Najat Rahman, Kecia Ali, Jerusha Tanner Rhodes, and Matthew Pierce focus on what ethics are imparted by the stories of specific prophets such as Abraham, Jesus, Muhammad, and the Shīì imams and how their masculinity figures in their exemplary status.

2 Although scholarship on women's Sufi hagiographies by Rkia Cornell (1999), Shaikh (2012) and Laury Silvers (2015) and others show that women too were thought to have spiritual connection, it was less worthy of record in hagiographies, and certainly not something that afforded women the kind of broadly accepted religious authority or legend that it did men. 
Najat Rahman's work leads us to analyse how idealised masculinity is achieved by looking at the narrative legacies of patriarchs. She argues that Abraham is not exemplary in his status as a son or father, but his family status is utilised in demonstrating exemplary belief in God. In combining analysis of Qurānic verses with literary depictions of Abraham as a figure of paternalism and nationalism, Rahman challenges Hebrew Bible constructions of Abraham as an exemplary patriarchal figure motivated by the "desire to have a son who will be the fulfilment of God's promise so that he can be a 'father of nations'" (2003, 299). Instead, Rahman argues that Abraham "occupies an ambivalent position in relation to paternity" in the Qurānic account of his role both because he is a son who disagreed with his father and as a father (and husband) who abandons his own son, Ishmael, and wife, Hagar, upon the command of God. She argues that this framing demonstrates that Muslim masculinity is defined by complete submission to God rather than embodied in the role of husband or father (Rahman 2003, 299). Rahman proposes that it is the myth, rather than the family life, of Abraham that constructs him as a figure of patriarchal nationalism (Rahman 2006, 82).

Amanullah De Sondy also argues that utter belief in God is the most important feature of prophetic careers, but for him family status is not incidental, but rather contributes to ideal tropes of masculinity, which are varied. He analyses Qur'ānic accounts of prophets' families and prophetic careers to argue that there is no singular paradigm of pious masculinity in Islam. The sexual and gendered discourses derived from the stories of Joseph, Muhammad, Adam, and Jesus - all of whom played various roles in disparate familial structuresreveal that the Qurān does not uphold an idealised or unified Islamic masculinity. Instead, he argues, that the prophets' "masculinity or masculinities are inextricably bound with the act of submission to God" rather than societal gender conventions (De Sondy 2015, 119). Likewise commenting on family, Omaima Abou-Bakr has contrasted premodern conceptions of Muslim masculinity from and modern ones in medieval tafsìr (exegesis) of the Qurān: "men are shown as having a domestic identity as well — that is, as members of the family, with duties to perform and a moral status to earn and acquire, depending mostly on obeying God's injunctions and not on biology" (Abou-Bakr, 10o). ${ }^{3}$

On the other hand, Matthew Pierce argues that comprehensive features that mark masculinity in the Shīi biographies of the twelve imams, were integral to shaping their religious authority. In conjunction with their holy genealogy,

3 I have argued that in the $a k h l a \bar{q}$ tradition sometimes establishing family and code of conduct within families are essential to ethical masculinity, but other times family is framed as incidental and expendable as men utilise them to improve their spiritual stations. 
moral teachings, and the miracles they performed through their prayers and intercession for their followers, their authority was constructed through descriptions of their perfect manly appearance (which biographers of different eras defined according to their own aesthetics), virility to sire children, love for family, especially children, and physical prowess. Their manly and gendered perfection were hallmarks of their authority as much as their relationship to God.

Kecia Ali and Jerusha Tanner Rhodes have focused specifically on Prophet Muhammad's exemplary character as a model husband. Kecia Ali has shown that the relational gender dynamic between Prophet Muhammad and his wives is not just important when it comes to Muslims' ethics of how men should treat their wives, but central to understanding Muslim beliefs about Muhammad as a man and a prophet (Ali 2014, 116-117). She analyses how modern biographies of the Prophet portray his exemplary moral character, by presenting his sayings and actions as historical facts that form a guide for Muslims' own behaviour which, as Omid Safi also examines, limited the mystical and miraculous elements of accounts of the Prophet's life (Ali 2014, 201-202; Safi 2010, 290). As a result, she demonstrates that the "authentic" sources that narrate the Prophet's life centre his relationships with women, particularly his wives, as sites for assessing his moral character. For example, his monogamous marriage to Khadija reflects his nobility and faithfulness since polygyny was a common practice in 7 th century Arabia, while, according to biographies mostly penned for non-Muslim Western audiences, the Prophet's marriage to 'Â'isha is often cited in order to question his moral character and virtues, and by extension, the ethics of the entire Muslim community (Ali 2014, 230).

Tanner Rhodes holds that the Prophet's maleness is of particular feminist concern because so much of the Sunna is made up of gendered and sexed practices "invoked to maintain the hierarchical status quo" (Rhodes 2018, 122). At the most obvious level, women are unable to emulate the Prophet as a father or husband, perform rituals such as ablution on the female body in the same manner as the male body or embody other gendered and sexed practices that make it so that "every detail and every sliver of emulation is an opportunity for growth and proximity to the Divine" $(2018,146)$. But, she argues that the Prophet's message can be framed as "destabilization of privilege - manifest in the theological and practical crossing of boundaries - that forms the kernel of Prophet Muhammad's model as a beautiful feminist exemplar" $(2018,149)$. This idea recasts his masculinity and gendered relationships to signify the Prophet's message to humanity, including the arc of his own biographical narrative, as a challenge and destabilises hierarchical privilege to restore only the hierarchy of the One with respect to all creation. By attending to the Prophet's maleness 
and drawing on Ayesha Chaudhry's question of why, given the Prophet's privilege in his own historical context, would he attempt to disrupt the status quo, Tanner Rhodes argues that the prophetic is rooted in the disruption of the status quo. Tanner Rhodes demonstrates that an attention to the Prophet's actions as a man in $7_{\text {th }}$ century Arabia doesn't negate the importance of Sunnah for both male and non-male people, but reveals novel behaviours and actions equally as worthy of emulation.

\subsection{Hegemonic Masculinity}

A useful way to think of masculinity in Islamic ethics is by focusing on how texts contrast between good men and bad men, specifically homing in on the prescriptive nature of texts and asking what kind of man (or men), and characteristics of manhood are being promoted and what kinds are denounced. This exercise ultimately leads us to thinking about how positive male attributes in Islamic ethics are also paternalistic ones. To do this, Raewyn Connell's concept of hegemonic masculinity is a useful tool to think with as it helps us to define the negative character traits that Islamic ethics texts caution against, as well as examine the textual hegemony regarding the positive character traits with which they are to be replaced.

Connell defines hegemonic masculinity as the worst, most base kind of behavioural traits that are also thought of as quintessentially masculine: "vehement and violent ... [with] severe cost, in terms of injury, ill health, and other constraints on life," yet being "honored or desired" (Connell 2003, 10-11). Initially, it seems to be a paradox of masculinity because aggressive behaviour beyond the norm is rare "in the statistical sense," but it is a set of behaviours that is associated with men only, and therefore can be construed as archetypical aggressive masculine traits that emerge from social and cultural pressure (especially in contrast to feminine traits), while also considered abhorrent and extreme (Connell and Messerschmidt, 832). Even though "only a minority of men might enact [hegemonic masculinity,] it was certainly normative [...] it required all other men to position themselves in relation to it, and it ideologically legitimated the global subordination of women to men" (Connell and Messerschmidt, 832). Although the concept has drawn some criticism for essentialising, simplifying male behaviour, and being static, hegemonic masculinity remains a key lens into how culturally normative maleness is constructed in relations between men, with women, non-binary, and queer individuals in a hierarchy of gender. In response to the critiques, Connell and Messerschmidt re-theorise that there are multiple cultural mechanisms for hegemony and acknowledge that hegemonic masculinity is culturally and 
temporally contextual. Also, they clarify that hegemonic masculinity "represents not a certain type of man but, rather, a way that men position themselves through discursive [and non-discursive] practices," while also acknowledging that individuals may possess or display multiple conflicting standards of masculinity, which are dynamic and interact with different kinds of masculinity and femininities (Connell and Messerschmidt 841, 844-845). Finally, also useful for thinking of Islamic ethics discourses is the idea of cultural change that is part of the reformulated version of hegemonic masculinity that accommodates a future positive hegemony of masculinity that is committed to gender equality (Connell and Messerschmidt, 853).

Although the concept is most easily employed in sociology, there are parallels to hegemonic masculinity in the Islamic ethics tradition because the discourse serves as a corrective to men's negative personal and relational conduct. The Qur'ān refers to al-nafs al-ammāra bi-l-sü' (evil predilections of the soul), or in the specific case of $a k h l a \bar{q}$, the kind of unmanly or emasculating behaviours caused by specifically male expressions of overindulging the concupiscent and irascible faculties of the nafs (soul). Islamic ethics texts attempt to curb this kind of base manhood, especially where scholars employ the term muruwwa (manhood) to discuss good behaviours that are synonymous with good behaviours for the soul and manliness. Thus, although the Islamic ethics tradition attempts to replace negative hegemonies of masculinity with positive ones, it is no less patriarchal in terms of prescribed hierarchy of gender and relations between men.

In the Sufi tradition, the disciplinary practice of javānmardī (male chivalry or young manliness) is "selflessness, loyalty to family and friends, and the observance of the rights owed to God" (Ridgeon 2011, 2). It is meant to correct hegemonic masculinity along with the rogue lifestyle originally associated with the term javānmardi, and it is also a path that, as its name implies, deliberately excludes women (Ridgeon 2011). There is no comparable term such as "young womanliness," just as the space for women in the sciences of self-refinement of $a k h l a \bar{q}$ or Sufism is limited to non-existent. By looking at corrective Islamic ethics discourses that use a framework of hegemonic masculinity and its opposites, an idealised, paternalistic masculinity emerges. Because so much of the appeals to the better natures of men within Islamic law and akhlāq are about interpersonal relationships, the performance of spiritual and ethical masculinity entails women and non-elite men's subjection. For example, in the Kimiyāy-yi Sa'ädat, al-Ghazālī instructs his reader not to marry if he cannot be good to his wife by explaining that marriage requires the discipline of his soul: "whoever cannot control his own nafs, it is better that he does not take charge 
of someone else's nafs" (Ayubi 2019a, 122). In addition to appealing to his better self, Ghazali also positions the husband as naturally superior to the wife. So, in the ethical correction, hegemonic masculinity is replaced by paternalism.

In his more recent work, Ridgeon examines the various ethics of the javānmardī of the felon, the faithful, and the fighter, to show that the heroic masculinity of a mystical nature was encompassed by the ability to do the right thing in a variety of circumstances (Ridgeon 2018). Ridgeon argues that the "elasticity [of javānmardī] also means that the concept is not tied to any particular ideology; it transcends the 'isms' of modernity, the exclusivism of religious denomination and perhaps, even gender distinctions" (Ridgeon 2018, 14-15). This echoes Connell's view that negative hegemonies can be replaced by positive ones, which in turn need not be only associated with men. However, as I noted above, women simply adopting ethics designed for men is fallacious and would require a shift in the ethical code or culture itself towards non-exploitation.

The Islamic ethics tradition's attempt to correct negative hegemonies with paternalism, is relevant in the tradition's deployment today as well. In contemporary apologetic scholarship about Muslim women's rights, the Islamic ethics objective of correcting hegemonic masculinity has led to the argument that "if men were to just follow real Islam" then women's problems such as spousal abuse or women's exploitation would resolve. For example, in her book, The Muslim Marriage Guide (1995), Ruqaiyyah Waris Maqsood cites al-Ghazālì's I $h y \vec{a}$ and other works to establish guidelines for a "The Good Husband," who financially supports his wife, shows her patience, and prioritises women's sexual pleasure; all of these qualities serve as a form of worship and establish that "the more civil and kind a Muslim is to his wife, the more perfect in faith he is, and the more worthy of being her leader" (Maqsood 1995, 55). The male normativity here is explicit: the "Muslim" here is the husband. Such arguments hold out hope for men to take the high road in their dealings with women based on the assumption that men want to achieve moral refinement or want ajr (the spiritual benefits). However, philosophical engagement with the akhlāq tradition shows that, on the contrary, men's refinement depends on the subjugation of women (Ayubi 2019a, 115). As Kecia Ali has argued, the claim that "if only men were to follow real Islam" also reveals a kind of apologetic attitude towards the legal tradition in that it focuses on minute legal accommodations for women that are subject to individual will, rather than acknowledging that men and women are fundamentally unequal legal subjects (Ali 2003, 164). At stake, argues Omaima Abou-Bakr argues are the very definitions of manhood and masculinity (Abou-Bakr, 102). The apologetic arguments underscore how the Islamic ethics tradition serves to replace hegemonic masculinity with paternalism. 


\subsection{Non-binary Gender in Premodern Islamic Ethics}

Employing gender critical lenses that include the study of masculinity will lead us to ask what beliefs about gender premodern ethicists of various genres held. Scholars such as Everett Rowson, Indira Falk Gesink, Scott Kugle, Ash Geissinger and Shireen Hamza have shown that premodern Muslim ethicists understood that some people's genders were non-binary. And while they did not conceive of gender as a critical category, premodern scholars spoke of gender roles, and characteristics of masculinity and femininity — all of which showed non-binary understandings. Hamza argues that while non-binary references are uncovered in scholarship on gender and sexuality in Islamic history, such references are not equally engaged in feminist Islamic legal studies (2020). One reason for the exclusion of non-binary references is that jurisprudential manuals are about "constructed legal ideals," rather than realities which included non-binary individuals (2020). Akhlāq texts are likewise concerned with establishing ideal practices, since ethicists identify behaviours, attitudes, and practices they associate with ideal morally and spiritually refined premodern men or muruwwa (manhood).

However, the study of masculinity in Islamic ethics (across genres) is uniquely positioned for traversing the ideal vs. real boundaries that regulate non-binary gender references since ideal notions of masculinity and men's ethical refinement were grounded in their social reality and achieved through men's relationship with subordinate, non-elite people, which would have included women, non-elite men, and gender minorities. Ethics texts of various genres include discussions about how to treat people based on what status they hold in society, so the texts would be relevant to the interface between conventional men and non-binary persons as well as the moral status of nonbinary people.

Non-binary references in pre-modern Islamic texts and the existence of gender minorities in premodern Muslim societies require scholars of Islamic ethics to abandon the assumption that male-female gender binaries were part of the socio-political realities that would have informed ethicists' understanding of morally and spiritually refined masculinity. Scholars have shown that a commitment to binary and heteronormative gender norms is incongruent with Muslim social history (Rowson 1991; Gesink 2018; Marmon 1995; El-Rouayheb 2005). Ash Geissinger's analysis of gender minorities in hadith literature demonstrates that premodern sources "do not present what we would regard as a unitary gender system," however, "they do construct a hierarchical view of gender, in which the freeborn Muslim adult, sane and able-bodied man, embodies hegemonic masculinity" (2021, 104). Geissinger argues for the utility of questions posed by queer and gender theory to produce "more careful 
analysis of representations of space, power and authority, social status, and intracommunal boundary negotiations in hadiths and tradition-based classical Muslim sources" (2021, 101-102). Utilising gender and queer theory to address the presence and absence of gender minorities in ethics texts enables a more nuanced understanding of the multiple power dynamics that would have informed ethicists definition of the masculine qualities possessed by a morally and spiritually superior man.

The relational aspect of Islamic ethics, in which ethical refinement is achieved over and against lesser forms of masculinity and femininity—which would have existed within non-elite men, women, and gender minorities like mukhannath (an effeminate man), khunthā (intersexed person), khunthā mushkil (medial sexed person) or eunuchs-places greater urgency on Geissinger's call for the use of queer theory in the questions scholars bring to premodern ethics texts. For example, what challenges did the existence of masculinity outside of male-marked bodies pose to men's ethical behaviour in the homosocial, public sphere and to their paternalism in the private sphere? Gesink has shown that premodern physicians, jurists, and lexicographers "tolerated ambiguity and flexibility regarding nonbinary sex embodiments" recognising "three to five sexual categories, including persons categorised as khunthā mushkil, for whom it was impossible to definitively determine whether someone is more male or more female or assign a "provisional' legal sex" (Gesink 2018, 152). As Marion Katz has noted about the concept of ghayra (manly pride), masculinity and masculine behaviours need not only belong to men in the ethical tradition, even if it is an overwhelmingly male emotion in ethics texts (Katz 2019, 202). Connell and Messerschmidt clarify from a sociological perspective that women and non-binary people may also perform masculine, and indeed hegemonic, masculine behaviours, in order to either find a place in or subvert gender hierarchy (Connell and Messerschmidt 2005, 847, 851).

If critical study of masculinity begins from the starting point that Muslim ethics has historically been written for men, then non-binary approaches towards gender and masculinity allows scholars to examine how morally superior, non-hegemonic masculinities were informed by gender hierarchies, as well as other forms of power and domination in premodern ethics texts. This requires scholars to assess the hegemonic masculinities present in ethicists' social contexts, the masculine characteristics ethicists wanted to refine, and the characteristics that needed to be preserved in order to maintain elite men's position in gender hierarchies. Rowson has argued that examining peripheral concepts of gender clarifies that dominance was a quality most essentially associated with masculinity. He proposes a method of looking at descriptions of physical characteristics that were lauded or desired in men to determine 
what was masculine, such as the presence and impressiveness of a beard, physical strength and ability to dominate, or virility perhaps measured by the biographers interest in remarking the number of children sired, which Peirce argues confirmed the Shī'ì imams' authority (Rowson 1991, 65-66; Pierce 2016, 100). Pierce and Rowson demonstrate that an attention to masculinity and its relationship to power in premodern contexts undermines gender binaries that assume masculinity was a quality possessed by all men based on binary notions of gender, rather than intimately linked to multiple representations of power.

The inclusion of non-binary renderings of gender into analyses of Islamic ethics furthers feminist scholarly goals by allowing scholars to theorise beyond the male normativity often assigned to ethics texts, by ethicists themselves and those that study them. Scott Kugle's close reading of Sufi notions of the body in Qurān and hadīth makes room for non-binary Muslim identities by insisting on dualism between the spirit and body, with the soul as a mediating identity that organises the body into a cohesive self (Kugle 2009). Thus, gender lies in the soul and "is not inherent in the body, but is rather a part of the personality which reflects upon the body" regardless of a person's anatomical parts (Kugle 2009, 238). Kugle traces the inclusion of non-binary gender identities in the Islamic scriptural tradition by arguing that the "Qur'an expresses God's speech in a profoundly complex interplay of genders, citing masculine and feminine while leaving room between them for ambiguity;" (Kugle 2009, 249). Accordingly, his later works take the form of contemporary Islamic ethics discourses that argue for the equality and inclusivity of LGBTQ Muslims (Kugle 2010, 2013). Shireen Hamza also calls for non-binary Muslims inclusion within feminist scholarship, specifically legal studies, based on her critical analysis of a possible reference to a non-binary individual by a Muslim jurist in a premodern Yemeni manuscript. Hamza argues that non-binary people's lack of inclusion in Islamic texts doesn't preclude feminist scholarship from being as "attentive to non-binary Muslim peoples as it is to Muslim women, past and present," and she proposes that feminist research in Islamic studies to draw on "growing social histories of the Islamic world to learn of - and fromnon-literate people" (2020). Applying a feminist lens, Sa'diyya Shaikh has described Ibn 'Arabī's use of gendered and sexual metaphors to signify not just relational dynamics between Sufis, but also signal his broad gendered understanding of human-divine relationships (Shaikh 2012, 123-124). She argues that partly a reflection of having had women teachers, Ibn 'Arabī's metaphors were indicative of his understanding of intercourse as creative, and his receptiveness to diverse gender subjectivities on a cosmic scale, even if he was located in male dominated practice (Shaikh 2012, 128). 
Hamza, Kugle, Geissinger, and Shaikh point to the theoretical and methodological possibilities for masculinity studies in Islamic ethics when non-binary notions of gender are accounted for in premodern Islamic ethics texts. This will ultimately require scholars to bring a diverse set of sources and analytical lens to ensure that the study of masculinity in Islamic ethics does not assign binary and heteronormative gender constructions to premodern Islamic texts.

\subsection{Interpreting Gender Segregation and Homosociality}

Homosociality is another key framework with which to analyse concepts of Muslim masculinity in premodern Islamic ethics texts, primarily because the ideal world of many of these texts is gender segregated and the code of ethics that are not specifically about marriage are generally about relationships between men. It entails comparing and contrasting roles of various men, competition between them, or rhetorical positioning of men in a hierarchy of superior and inferior according to their performance of virtues, lower class, or sinful men. Many akhlāq texts in particular extol men's relationships with each other as the purest form of love, and are also laced with denigrating comments about women as irrational, and therefore imperfect companions for men. Men's and women's relations with one another are best confined to the corporeal, whether describing the mother and son birthing and nursing relationship, or husband and wife sexual relations. Because men's relationships to other men encompass the cerebral, the friendly, the professional, and all other types of relations, male homosociality is a vital and valuable framework for understanding idealised masculinity.

The work of a few specific theorists is relevant to creating a framework for studying homosocial masculinity in premodern Islamic ethics texts. Sylvia Walby's idea that patriarchy emerges in different ways in public than it does in private is particularly helpful because of premodern texts' idealised confinement of women to the private realm (Walby 1990, 178-179). Although scholars have critiqued Walby's use of temporal phases to describe the emergence of patriarchy (first in private and then in public), we are already familiar with the what she describes as the patriarchy of gender relations of the private phase in premodern Islamic ethics; we are less familiar with how men compete with other men in the formation of a public phase of patriarchy. Connell explains that masculinities themselves are hierarchical: "Different masculinities do not sit side-by-side like dishes on a smorgasbord. [...] There are relations of hierarchy, for some masculinities are dominant while others are subordinated or marginalized" (Connell 2003, 10). Islamic ethics especially in the intellectual tradition regarding men's relationships with male friends, acquaintances, enemies, superiors in profession or social rank, and relationships with inferiors 
such as pupils, slaves, servants, or professional or social subordinates, are telling of the kind of masculinity that is prised and how that comes about in men. Relationships between male family members, which take place in the private realm, at least in the $a k h l \bar{q} q$ tradition, are about fathers training their sons to become ethical men in private and public. Keeping this theorisation in mind, one can study articulations of masculinity and manhood across multiple genres of Islamic ethics.

The strategy of examining homosociality and gender segregation for studying masculinity in Islamic ethics texts emerges from reflecting on the upshot of prescribed gender segregation, meaning that the ethics of social relations really are imagined as male homosocial interactions. As such male-male interactions in the texts become important data for understanding how masculinity is constructed over and against femininity, but also against lesser states of masculinity. For this analysis one must look at the ethical and legal characteristics of the relationships between men including friendships, family ties, and relationships of master-disciple, master-slave, king-subject and so on. What is legal or ideal conduct in such relationships and how are they hierarchical? How are men supposed to greet each other, what kind of speech should they use to support or disparage each other? How are equals supposed to behave, especially when they compete for favours? What kind of conduct among men is transgressive with respect to enmity or love? In Gendered Morality, I ask these questions through the method of reading for homosociality (Ayubi 2019a, 175-237). I find that the ethics of male homosocial relationships are the pillars upon which patriarchy stands in akhlāq cosmologies. The prescriptive behaviours between men, sometimes using women has rhetorical devices, bolster stratification of male realms of society as well as exclusion of women and non-elite men from the highest echelons of society.

Just as masculinity has been universalised, so too have male-male homosocial relationships been universalised as friendship, brotherhood, collegiality, masters and disciples, kings and courtiers, etc. Many scholars have investigated such relationships, in Islamic history or even premodern ethics texts, though often without the lens of homosociality specifically.

For example, Shahzad Bashir has examined the study of the male masterdisciple relationships in premodern Sufi texts to illustrate that men's ability to transcend lesser forms of masculinity depends on their literal and metaphysical proximity to the prised masculinities possessed by Sufi masters (Bashir 2011, 108-129). Bashir proposes that the purpose of these "in between identities" of Sufis as masters and disciples "ratify the transmission of Sufi authority" and that depicting "the body of the disciple [as] interchangeable with that of the master was the most emphatic means of legitimating succession" $(2011,129)$. 
This male homosocial relationship is not just the medium for reaching God, it shows how premodern Muslim men in ideal Sufi states behaved with one another as they oriented themselves to God, which required establishing intimate relationships with masters who possessed spiritual and social authority.

Focusing on how hierarchical homosocial Sufi relationships are created, Margaret Malamud traces how authors of classical Sufi manuals used gendered imagery to "aid in describing a hierarchical relationship between men, one based on authority and dependence and dominance and submission" (Malamud 1996, 9o). In addition to using terms such as guide, teacher, novice, or student to describe Sufi masters and disciples, the manuals also employed terms and tropes associated with women such as mother, beloved, child, lover, bride to position men as superiors, subordinates, nurturers, and givers or receivers of knowledge or favours. The gendered imagery associated with women's procreative and nurturing powers affirmed the authority of the master (Malamud 1996, 101-102). Here texts about men rhetorically employ women, in this case to analogise the master-disciple relationship. Malamud analyses this relationship as hierarchical submission and a reflection of medieval hierarchical social relationships reliant on submission and authority, such as the fatherson relationship, 'ulam $\bar{a}^{\prime} /$ religious scholar-student relationship, ruler-subject, and ultimately, the God-believer relationship (1996).

Often in premodern Islamic ethics, as in the subjects of Bashir, Malamud, and my own works, we find virtuous manhoods were not only constructed over and against femininity or women, but were dependent on both intimate and hierarchical relationships between men. Ultimately, one is able to understand who is considered elite and who is excluded. Thus, employing gender frameworks, inclusive of masculinity, and specifically homosociality, gives us a richer understanding of Islamic ethics. Bashir and Malamud's critical analyses of master-disciple relationships, as but one example, impress upon us the importance of homosocial relationships in men's ethical refinement and reveal that an attention to masculinity provides insight into premodern and medieval social structures and concepts of love. Furthermore, Bashir's attention to embodied Sufi practices reveals that men's ethical refinement is complex and relies on intimate embodied practices that blur distinctions between individual men. Here, an attention to masculinity shows that gender, specifically masculinity and the maleness of bodies, plays an important role in Islamic ethics texts, regardless of whether real or imagined women are present. In other words, gender (and masculinity) is still important even when the texts are only about men or historically men's realms and can be studied using the lens of homosociality. Adding an analysis of homosociality to one's methodology 
leads to a richer analysis of how patriarchy fortifies itself among men and shapes manhood.

\subsection{Masculinity in Contrast to Femininity}

A major scholarly method for studying masculinity, and the most common, is to examine the presence or absence of women and femininity in the texts. Connell and Messerschmidt argue that the study of masculinities "needs to incorporate a more holistic understanding of gender hierarchy, recognising the agency of subordinated groups as much as the power of dominant groups and the mutual conditioning of gender dynamics and other social dynamics" (Connell and Messerschmidt). This entails contrasting the prescriptive ethical behaviours with known social histories of women's lives, which clarifies ethics texts' male normativity and women's exclusion, or also analysing the rhetorical use of women often as immoral or irrational foils of men.

Scholars' works on gender contrasts can be categorised into three methods, depending on the type of ethics texts they study: first is to consider what function representations of women in ethics texts served given ethicists' social historical contexts and their intended male audiences; the second is to examine idealised masculinity in ethical gender relations in comparison with contemporaneous social history material when ethics texts are advocating for gender segregation and women's seclusion; and the third is to examine masculinity in relation to hypothetical femininity in texts in which women's moral agency is absent altogether and replaced with hypothetical women with inferior morals. Like in the first methods I presented on de-universalising male normative ethical subjects by reflecting on their masculinity, much of existing scholarship, in this case on women and femininity, can be revisited to analyse how men and manhood are constructed in relation to women, which will enable feminist scholars to identify and ultimately deconstruct what makes men superordinate in premodern texts.

In the first category, mentions of historical women in premodern texts, show how mentions of women were used to bolster men's ethical status. Scholars must ask: if the audience of these texts are elite men, why is mentioning ideal womanly behaviour, which may or may not have matched women's actual social realities, relevant to ethicists' male audiences and their understandings of masculinity? Nadia El Cheikh's study of mentions of women in 'Abbāsid texts is a precise example of this. She shows that for early Muslims the narratives of Mary, Khadija, 'Â'isha, and Fāțima (among other women) were couched in a "rhetoric of exemplarity that recorded their merits," which served to establish the parameters of a new Muslim personhood set against "ethical opposites: of 
Islamic virtues that would allow the world to prosper, and the jāhilizy $a$ or nonIslamic principles that would lead to its destruction," (El Cheikh 2015, 114-115). Mary, Khadijja, 'Āisha, and Fāțima not only represented ideal womanly behaviour, but were "constructed to symbolise key aspects of the Islamic struggle for the maintenance of the boundaries of Muslim identity" for 'Abbāsids in their competition with jāhili Arabs, the Byzantine Christians, and the Qarāmița (El Cheikh 2015, 114-116). In this case, contrasting representations of revered woman figures with the social reality of Abbasid texts reveals that representations of women played an integral role in upholding the superiority of Abbasid men over rivals of their time. Likewise, Roxanne Euben has shown that the 14th century scholar-traveller Ibn Battuta conveyed to his readers of his travel narrative, albeit not an ethics text but not without moral commentary, the value of the civilisations he encountered in his journeys by evaluating the piety, seclusion, beauty, and chastity of women of those places (Euben 2006, 80-81). These works demonstrate how mentions of historical women in texts by, for, or describing men signified the moral values of men of their societies whom they represented.

Although premodern ethics genres are idealistic, the texts do respond in some ways to reality. In the process of using the second method of searching for constructions of masculinity via men's relations with women, it is important to historically contextualise ethical calls for gender segregation, women's seclusion, and what amounts to exclusion of women from the ethical enterprise (Lutfi 1991, 101-102; Ayubi 2019a, 11). In comparing the textual recommendations to seclude "their" women, prevent them from reading or writing, or to be otherwise zealous in guarding their presence from strangers or outside the home, we see in this social history a particular kind of masculinity emergingone that is secured by relegating women to the private sphere. The rhetoric of gender segregation, read this way, says more about manhood, for instance, the concept of manly ghayra (pride) over women, and how male spaces are created, and expectations about male sexuality, than about the actual or idealised status of women.

Contrasting women's social reality, as shown in social history material, with the ethics of gendered relationships allows scholars to critically approach gender relations as idealised representations in ethics texts rather than as historical facts (which they are not), and masculinity as constructed rather than innate. Historians have shown that the presence of men and women in both public and private spaces were fluid. For instance, analysing 1oth century artistic evidence on Persianate women in the Seljuq period, Carole Hillenbrand challenges depictions drawn from analysis of legal texts of premodern Persianate women as underlings confined to the home and absent in public 
life due to their meddlesome nature in public religious and political spaces (Hillenbrand 2003). She argues that Seljuk (Saljūq) travel writings, paintings, historical chronicles, and architectural patronage demonstrate that women had a presence-no doubt limited by the constraints of their male dominated societies - in politics, attended mosques, and moved within the public sphere; suggesting that "evidence of the ulama's writing should be treated with caution: they speak about what should be rather than what is" (Hillenbrand 2003, 116). Likewise, Marion Katz's survey of women's mosque access in classical Sunnī law as compared to non-legal sources reveals that the restrictions placed on women's mosque access reflected jurists' idealised norms and were a response to women's active participation in public ritual life; thus, "the jurists' role was often reactive; [and] in many cases, scholars were left to bemoan activities that they were unable effectively to control" (Katz 2014, 198). Most premodern Islamic ethics texts, particularly the intellectual tradition rather than the scriptural tradition, either assume or prescribe gender segregation. In addition to a richer understanding of women's status, the contrast between the rhetoric of seclusion and the social history of its more and less successful implementation, leads us, more profoundly, to questions about what kind of masculine space ethics texts are attempting to create and preserve through the assumed exclusion of women and how idealised masculinity in ethics texts arises in prescribed acts of secluding women.

Finally, the third possibility for how to study masculinity in ethics texts through femininity or women, is examining their absence as moral subjects and presence as rhetorical devices. In texts that exclusively address men-as evidenced by the subject matter such as speaking to men about how to find a wife with ideal qualities (Ayubi 2019, 124-132), or the legalities of waliss (male guardians) marrying off minor children (Ali 2010, 30-35) - it is possible to examine what constitutes male superiority. Marion Katz has shown that while women too were thought to be able to possess ghayra in the sense of "petty jealousy" they were believed to possess the opposite, haya $\bar{a}^{\prime}$ (modesty) instead (Katz 2014b; Katz 2019, 203). She shows how Ibn Qayyim al-Jawziyya employed a highly gendered understanding of ghayra as a normative masculine characteristic and emotion that could be over or under expressed. For him it encompassed pride, jealousy that prompted one to seclude one's womenfolk, zeal for God that led to enforcement of God's decrees. As a hegemony of male behaviour ghayra was a "theological and social virtue [... that was] volatile and potentially destructive" and a "fundamentally amoral drive that is only secondarily disciplined by moral guidance" (Katz 2019, 215). Because texts in these examples only address men and their concerns, scholars often make the masculine into the universal, while ignoring rhetorical appearances by women. In 
a subtle way, in legal texts on 'ibādāt (worship) or spiritual or ethical training in the case of Sufi manuals or akhlāq texts, idealised masculinity emerges from how hypothetical women are treated as moral foils.

As opposed to their limited presence in the non-exhaustive historical examples I mentioned above, women in ethics texts are missing as agents themselves, but appear in didactic vignettes that premodern jurists, philosophers, and ethicists used as tools to "think with," in order to establish proper male conduct and responsibility (Shapiro 1997, 165). For example, in an exposition on responsibility towards friends, al-Ghazālī relates a story in which a man and his friend go to a hill to pray, and when the friend goes into the city for food he is distracted by a "bad woman," likely a prostitute, with whom he spends several days. When the man goes to the city and finds his friend with the bad woman, the friend is embarrassed. To snap the friend out of the spell of the bad woman, the man embraces the friend, kisses him, and affirms their friendship; after, the friend leaves the company of the bad woman and repents. Here, men's ideal behaviour is explained through the contrast of the righteous man with the immoral or lesser women. Al-Ghazālī uses the bad woman to "think with" and affirm homosocial male relationships as superior because they are based on true love and male superiority (Ayubi 2019a, 19o). In another akhlāq example, Nașīr al-Dīn Ṭūsī likewise defines proper dress for a boy by describing concern with clothing and arranging hair as the domain of women and frivolous (Ayubi 2019b, 1194).

Fedwa Malti-Douglas reads Ibn Țufayl's (d. 581/1185) Hayy ibn Yaqzān as a story of a male utopia "to call attention to the problem of gender, to the play of male and female, in Ibn Tufayl's text" (1991, 69). Hayy, the protagonist, is raised by a gazelle on an isolated Island. The narrator shares two stories of Hayy's birth account, one where Hayy's mother sets him afloat in a river because he was the product of a forbidden and "clandestine marriage to her brother's relative;" the other narrative attributes Hayy's inhabitation of the island to a spontaneous birth without a mother or father. Malti-Douglas argues that these two accounts "taken separately or together, reflect manifest ambivalence and barely concealed anxiety/hostility to the idea of motherhood" (1991, 74). Later, Hayy comes into contact with a neighbouring man and together they leave the island, only to return to Hayy's utopian territory together. Here, Malti-Douglas argues that the nurturing gazelle stands in contrast to his biological mother and that "this two-brother relationship is no accident. One can argue that it (as in al-Ghazâlī, we might add) represents an idealised Islamic social relationship [...] And this is where Ibn Tufayl's male Utopia comes in. Though limited, it is a society of men and hence, by implication, of fellowship" (Malti-Douglas, 
82). The hypothetical women in al-Ghazālī, Ibn Ṭufayl, and Țūsì's works demonstrate both that even in normative male ethics texts in which accounts of historical women or of women's roles in the ethical enterprise are missing, hypothetical women are often present as moral foils to men. Mentions of women as rhetorical devices are usually brief, but establish what is the proper masculine and ethical conduct or value.

In ethics texts, men's relationships with women, prescribed attitudes towards women, as well as rhetorical uses of women, explain ideas about ethical masculinity through femininity. The presence, absence, or rhetorical use of women in ethical sources has the potential to tell us more about the male dominated world of ethics than just asking questions about women's status in the texts. We know that no absolute public-versus-private binary or complete segregation existed historically and thus, idealised relationships with women tell us about idealised masculinity, whether of prophets or other ethical men.

\section{3}

\section{Conclusion}

In closing I want to reiterate what is to be gained from reading Islamic ethics texts for concepts of gender, inclusive of masculinity from a feminist perspective. Such study provides a crucial understanding of how metaphysics, ontology, the very nature of creation, and moral responsibility in Islamic discourses are hierarchical, exclusionary, and rooted in elite male normativity. Tracing masculinity in premodern Islamic ethics discourses helps us understand a major epistemological blockade within moral thought more fully; namely that because most genres of Islamic ethics are written by and for (elite) men, nonelites do not have access to it. De-universalising male normativity is a major step towards understanding gender asymmetry in Islam and towards inclusivity in Islamic ethics. Studying masculinity in Islamic ethics shows us how ideal types of manhood are constructed through concepts of family and relationships; that traits that are thought to be masculine may not always belong to men and that Islamic ethics frameworks have historically espoused non-binary concepts of gender, even while championing particular corrective discourses; that although Islamic ethics attempts to curb hegemonic masculinity, its replacement with paternalism is also a hegemony, but one that can shift yet; that gender segregation is not just a mechanism for oppressing women, but that its companion, homosociality, is a lens through which we can see that patriarchy rests upon competition, friendship, and relationships between men; and 
finally that femininity and women are often used as foils or tropes to bolster particular hegemonic or positive idealistic types of masculinity. In short, at stake in employing lenses to study masculinity in Islamic ethics discourses are existential questions of what it means to be a moral and ethical Muslim.

\section{Bibliography}

Abou-Bakr, Omaima. 2013. "Turning the Tables: Perspectives on the Construction of 'Muslim Manhood." Hawwa 11(2-3): 89-107.

Ahmed, Mohammad. 2009. "Islamic feminism: Is that an oxymoron?" Darul Ihsan Studies 3 (December): 53-67.

Ahmed, Leila. 1992. Women and Gender in Islam: Historical roots of a modern debate. New Haven: Yale University Press.

Ali, Kecia. 2002. "Rethinking Women's Issues in Muslim Communities." In Taking Back Islam:Americans Reclaim Their Faith, edited by Michael Wolfe, 91-98. Gordonsville: Rodale.

Ali, Kecia. 2003. "Progressive Muslims and Islamic Jurisprudence: The Necessity for Critical Engagement with Marriage and Divorce Law." In Progressive Muslims on Justice, Gender and Pluralism, edited by Omid Safi, 163-189. London: Oneworld Publications.

Ali, Kecia. 2010. Marriage and Slavery in Early Islam. Cambridge, MA: Harvard University Press.

Ali, Kecia. 2012. "Muslim Masculinities: Men Have Gender Too." Feminism and Religion. https://feminismandreligion.com/2012/o8/21/muslim-masculinities-men-have-gen der-too-by-kecia-ali/.

Ali, Kecia. 2014. The Lives of Muhammad. Cambridge, MA: Harvard University Press. Ayubi, Zahra. 2019a. Gendered Morality: Classical Islamic Ethics of the Self, Family, and Society. New York: Columbia University Press.

Ayubi, Zahra. 2019b. "Rearing Gendered Souls: Childhood and the Making of Muslim Manhood in Pre-modern Islamic Ethics." Journal of the American Academy of Religion 87(4): 1178-1208.

Ayubi, Zahra. 2020. "Islamic Gender Ethics: Traditional Discourses, Critiques, and New Frameworks of Inclusivity." In Routledge Handbook of Islam and Gender, edited by Justine Howe, 57-67. London: Routledge.

Bashir, Shahzad. 2011. Sufi Bodies: Religion and society in medieval Islam. New York: Columbia University Press.

Connell, Raewyn. 2003. The Men and the Boys. St. Leonards, NSW: Allen \& Unwin.

Connell, Raewyn and James Messerschmidt. 2005. "Hegemonic Masculinity: Rethinking the Concept." Gender \& Society 19(6): 829-859. 
Cornell, Rkia E. 1999. "Introduction: As-Sulami and his Sufi Women." In Early Sufi Women: Dhikr an-Niswa al-Muta'abbidāt aṣ-Șufiyyāt, edited by Abū 'Abd ar-Raḥmān as-Sulamī, translated by Rkia Cornell. Louisville: Fons Vitae.

De Sondy, Amanullah. 2015. The Crisis of Islamic Masculinities. London: Bloomsbury.

El Cheikh-Saliba, Nadia. 2015. Women, Islam and Abbasid Identity. Cambridge, MA: Harvard University.

El-Rouayheb, Khaled. 2005. Before Homosexuality in the Arab-Islamic World, 1500-1800. Chicago: University of Chicago Press.

Ernst, Carl W., and Richard C. Martin, eds. 2012. Rethinking Islamic Studies: From Orientalism to Cosmopolitanism. Columbia, SC: University of South Carolina Press.

Euben, Roxanne. 2006. Journeys to the Other Shore: Muslim and Western Travelers in Search of Knowledge. Princeton: Princeton University Press.

Gabbay, Alyssa. 2020. Gender and Succession in Medieval and Early Modern Islam: Bilateral Descent and the Legacy of Fatima. London: I.B. Tauris/Bloomsbury.

Geissinger, Ash. 2020. "Applying Gender and Queer Theory to Pre-Modern Sources." In Routledge Handbook of Islam and Gender, edited by Justine Howe, 101-115. London: Routledge.

Gerami, Shahin. 2005. "Islamist Masculinity and Muslim Masculinities." In Handbook of Studies on Men and Masculinities, edited by Michael S. Kimmel, Jeff Hearn and R. W. Connell, 448-457. Thousand Oaks, CA: Sage Publications.

Gesink, Indira Falk. 2018. "Intersex Bodies in Premodern Islamic Discourse: Complicating the Binary." Journal of Middle East Women's Studies 14(2): 152-173.

Hamza, Shireen. 2020. "Annulling the Marriage of Two Men: Marginal Note in a Yemeni Manuscript" Journal of the History of Ideas Blog. https://jhiblog.org/2020/06/10/ annulling-the-marriage-of-two-men-a-marginal-note-in-a-yemeni-manuscript/.

Hillenbrand, Carole. 2003. "Women in the Saljuq Period." In Women in Iran from the Rise of Islam to 1800 , edited by Guity Nashat and Lois Beck, 103-120. Champaign, Il: University of Illinois Press.

Inhorn, Marcia. 2012. The New Arab Man: Emergent Masculinities, Technologies, and Islam in the Middle East. Princeton: Princeton University Press.

Katz, Marion. 2014. Women in the Mosque: A history of legal thought and social practice. New York: Columbia University Press.

Katz, Marion. 2014b. "Shame (Haya $)$ ) as an Affective Disposition in Islamic Legal Thought" Journal of Law, Religion and State 3(2): 139-169.

Katz, Marion. 2019. "Beyond Halāl and Harām: Ghayra (Jealousy) as a Masculine Virtue in the Work of Ibn Qayyim al-Jawziyya” Cultural History 8(2): 202-225.

Kugle, Scott Siraj al-Haqq. 2010. Homosexuality in Islam: Critical reflection on gay, lesbian, and transgender Muslims. Oxford: Oneworld Publications.

Lutf, Huda. 1991. "Manners and Customs of Fourteenth-Century Cairene Women: Female Anarchy Versus Male Shari Order in Muslim Prescriptive Treatises," in 
Women in Middle Eastern History: Shifting Boundaries in Sex and Gender, edited by Nikki Keddie and Beth Baron, 99-121. New Haven: Yale University Press.

Malamud, Margaret. 1996. "Gender and Spiritual Self-Fashioning: The Master-Disciple Relationship in Classical Sufism." Journal of the American Academy of Religion 64(1): 89-117.

Malti-Douglas, Fedwa. 1991. Woman's Body, Woman's Word: Gender and discourse in Arabo-Islamic writing. Princeton: Princeton University Press.

Maqsood, Ruqaiyyah Waris. 1995. The Muslim Marriage Guide. London: Quilliam.

Marmon, Shaun. 1995. Eunuchs and Sacred Boundaries in Islamic Society. Oxford: Oxford University Press.

Mir, Shabana. 2014. Muslim American Women on Campus: Undergraduate Social Life and Identity. Chapel Hill: The University of California University Press.

Mir-Hosseini, Ziba. 2003. "The Construction of Gender in Islamic Legal Thought and Strategies for Reform." Hawwa 1(1): 1-28.

Myrne, Pernilla. 2019. Female Sexuality in the Early Medieval Islamic World: Gender and Sex in Arabic Literature. London: I.B. Tauris.

Omar, Sara. 2012. "From Semantics to Normative Law: Perceptions of Liwāt (Sodomy) and Sihâq (Tribadism) in Islamic Jurisprudence (8th-15th century CE)." Islamic Law and Society 19(3): 222-256.

Ouzgane, Lahoucine. 2006. Islamic Masculinities. London: Zed Books.

Peretz, Tal. 2016. "Why Study Men and Masculinities? A Theorized Research Review" Graduate Journal of Social Science 12(3): 30-43.

Pierce, Matthew. 2016. Twelve Infallible Men: The Imams and the Making of Shicism. Cambridge, MA: Harvard University Press.

Rahman, Najat. 2003. "The Trial of Heritage and the Legacy of Abraham." Men and Masculinities 5(3): 295-308.

Rhodes, Jerusha Tanner. 2018. Divine Words, Female Voices. Oxford University Press.

Ridgeon, Lloyd, ed. 2018. Javanmardi: The Ethics and Practice of Persianate Perfection. London: Gingko.

Ridgeon, Lloyd. 2011. Jawanmardi: A Sufi Code of Honour. Edinburgh: Edinburgh University Press.

Rowson, Everett. 1991. "The Categorization of Gender and Sexual Irregularity in Medieval Arabic Vice Lists." In Bodyguards: The Cultural Politics of Gender Ambiguity, edited by Julia Epstien and Kristina Straub, 50-79. London: Routledge.

Safi, Omid. 2010. Memories of Muhammad. New York: Harper Collins.

Saloojee, Riad. "Etiquettes of Marriage-Renewing Religion: An Overview of Ghazali's Ihya." Lecture, SeekersGuidance: The Global Islamic Seminary, June 8, 2017. www .youtube.com/watch?v=wjxxmo2-gjU\&t=66os.

Shaikh, Sa'diyya. 2012. Sufi Narratives of Intimacy: Ibn Arabi, Gender, and Sexuality. Chapel Hill: University of North Carolina Press. 
Shapiro, Susan. 1997. "A Matter of Discipline: Reading for Gender in Jewish Philosophy." In Judaism Since Gender, edited by Miriam Peskowitz and Laura Levitt, 158-173. New York: Routledge.

Silvers, Laury. 2015. "Early Pious, Mystic Sufi Women." In Cambridge Companion to Sufism, edited by Lloyd Ridgeon, 24-52. New York: Cambridge University Press.

Spellberg, Denise. 1994. Politics, Gender, and the Islamic Past: The Legacy of 'A'isha bint Abi Bakr. New York: Columbia University Press.

Stowasser, Barbara. 1994. Women in the Qur'an: Traditions and Interpretation. Oxford: Oxford University Press.

Walby, Sylvia. 1990. Theorizing Patriarchy. Cambridge, MA: Basil Blackwell.

Zargar, Cyrus Ali. 2017. The Polished Mirror: Storytelling and the Pursuit of Virtue in Islamic Philosophy and Sufism. London: Oneworld Publications. 